\title{
Study the Concentration of Naturally Occurring Radioactive Materials in the Samples of Rice and Salt in Baghdad Governorate
}

\author{
Ban. S. Hameed, Basim K. Rejah and Sara S. Muter \\ Department of Physics, College of Science for Women, University of Baghdad, Baghdad-Iraq.
}

\begin{abstract}
In this study, specific activities of naturally occurring radioactive materials were measured in selected samples of rice and salt available in local markets in Baghdad and then calculate hazard indices as well as the concentration of radioactive iodine in these samples using the detector system sodium iodide enhanced by thallium $\mathrm{NaI}(\mathrm{Tl})$. This study showed that the average quality of the specific activities of uranium 238 was $5.55 \mathrm{~Bq} / \mathrm{kg}$, thorium 232 was $5.6 \mathrm{~Bq} / \mathrm{kg}$ and potassium 40 was $621 \mathrm{~Bq} / \mathrm{kg}$, while the content of iodine was $1312.6 \mathrm{~Bq} / \mathrm{kg}$.

Measurements of hazard indices show that the concentrations of these isotopes in all samples are within the allowable limits internationally except Al-Nasoor sample which was the total of Hinternal and Hexternal indices more than one. All data were measured at the January of 2015.
\end{abstract}

Keywords: Concentrations of naturally occurring radioactive materials, Hazard indices, Hinternal and Hexternal indices.

\section{Introduction}

Environment pollution is a worldwide problem and its potential to influence the health of human population is great. Human exposure to pollution is believed to be more intense now than at any other time in human activity and by natural forces as well. Selfish private enterprise and their lack awareness of public well-being and social costs. There is not doubt excessive levels of pollution are causing lot damage to the human and animal health [1]. Radioactive is isotope of elements (radio nuclides) are naturally present in the environment from natural series ${ }^{238} \mathrm{U},{ }^{232} \mathrm{Th}$ and ${ }^{40} \mathrm{~K}$ and that includes our bodies, our foods and water. Occurring radioactive materials (radio nuclides) found in the soil, water and air. Radioactivity can be detected in food, water and the concentration of naturally occurring radionuclides varies depending on several factor such us local geology [2]. The amount of radiation people are exposed to varies from place to place and individuals [2,3]. The overall consequence pose by ecological degradation has been proved to be insidious as many cancerous diseases [4].

\section{Hazard Indices}

\section{Radium Equivalent Activity (Raeq).}

Radium equivalent activity $\left(\mathrm{Ra}_{\mathrm{eq}}\right)$ is a common index used to compare the specific activities of materials containing ${ }^{226} \mathrm{Ra},{ }^{232} \mathrm{Th}$ and ${ }^{40} \mathrm{~K}$ by a single quantity, which takes into account the radiation hazards associated with them [5]. The activity index provides a useful guideline in regulating the safety standard dwellings.

The radium equivalent activity represents a weighted sum of activities of the above mentioned natural radionuclides and is based on the estimation that $1 \mathrm{~Bq} / \mathrm{kg}$ of ${ }^{226} \mathrm{Ra}, 0.7$ $\mathrm{Bq} / \mathrm{kg}$ of ${ }^{232} \mathrm{Th}$, and $13 \mathrm{~Bq} / \mathrm{kg}$ of ${ }^{40} \mathrm{~K}$ produce the same radiation dose rates.

The radium equivalent activity index is given as [6]:

$\mathrm{Ra}_{\mathrm{eq}}=\mathrm{C}_{\mathrm{Ra}}+1.43 \mathrm{C}_{\mathrm{Th}}+0.077 \mathrm{C}_{\mathrm{K}}$

where: $\mathrm{C}_{\mathrm{Ra}}, \mathrm{C}_{\mathrm{Th}}$ and $\mathrm{C}_{\mathrm{K}}$ are the radioactivity concentration in $\mathrm{Bq} / \mathrm{kg}$ of ${ }^{238} \mathrm{U},{ }^{232} \mathrm{Th}$ and ${ }^{40} \mathrm{~K}$, respectively.

The use of material whose Raeq concentration exceeds $370 \quad \mathrm{~Bq} / \mathrm{kg}$ is discouraged to avoid radiation hazards [7].

\section{Annual Effective Dose Equivalent (AEDE)}

The annual effective dose equivalent received outdoor by a member is calculated from the absorbed dose rate by applying dose conversion factor of $0.7 \mathrm{~Sv} / \mathrm{Gy}$ and the occupancy factor for outdoor and indoor was $0.2(5 / 24)$ and $0.8(19 / 24)$, respectively [8]. AEDE is determined using the following equations: 
AEDE (Outdoor) $(\mathrm{mSv} / \mathrm{y})=$ Absorbed dose $(\mathrm{nGy} / \mathrm{h}) \times 8760 \mathrm{~h} / \mathrm{y} \times 0.7 \mathrm{~Sv} / \mathrm{Gy} \times 0.2 \times 10^{-6}$

AEDE (Indoor) $(\mathrm{mSv} / \mathrm{y})=$ Absorbed dose $(\mathrm{nGy} / \mathrm{h}) \times 8760 \mathrm{~h} / \mathrm{y} \times 0.7 \mathrm{~Sv} / \mathrm{Gy} \times 0.8 \times 10^{-6}$

\section{External Hazard Index ( $\left.\mathrm{H}_{\mathrm{ex}}\right)$.}

Many radionuclides occur naturally in terrestrial soils and rocks and upon decay, these radionuclides produce an external radiation field to which all human beings are exposed. In terms of dose, the principal primordial radionuclides are ${ }^{232} \mathrm{Th},{ }^{238} \mathrm{U}$ and ${ }^{40} \mathrm{~K}$. Thorium and uranium head series of radionuclides that produce significant human exposure. The external hazard index $\left(\mathrm{H}_{\mathrm{ex}}\right)$ is defined as [6]:

$\mathrm{H}_{\mathrm{ex}}=\mathrm{C}_{\mathrm{Ra}} / 370+\mathrm{C}_{\mathrm{Th}} / 259+\mathrm{C}_{\mathrm{K}} / 4810$

The value of this index must be less than unity for the radiation hazard to be negligible [6]. $\mathrm{H}_{\mathrm{ex}}$ equal to unity corresponds to the upper limit of Raeq $(370 \mathrm{~Bq} / \mathrm{kg})$ [6].

\section{Internal Hazard Index (Hin).}

The internal hazard index $\left(\mathrm{H}_{\text {in }}\right)$ is given as[6]:

$\mathrm{H}_{\text {in }}=\mathrm{C}_{\mathrm{Ra}} / 185+\mathrm{C}_{\mathrm{Th}} / 259+\mathrm{C}_{\mathrm{K}} / 4810$

$\mathrm{H}_{\mathrm{in}}$ should be less than unity for the radiation hazard to be negligible. Internal exposures to radon are very hazardous this can lead to respiratory diseases like asthma and cancer.

\section{Representative Gamma Index ( $\left.\mathrm{I}_{\gamma \mathbf{r}}\right)$.}

Representative Gamma Index is used to estimate the $\gamma$ - radiation hazard associated with the natural radionuclide in specific investigated samples. The representative gamma index as [9]:

$\mathrm{I}_{\gamma \mathrm{r}}=\mathrm{C}_{\mathrm{Ra}} / 150+\mathrm{C}_{\mathrm{Th}} / 100+\mathrm{C}_{\mathrm{k}} / 1500$

This gamma index is also used to correlate the annual dose rate due to the excess external gamma radiation caused by superficial materials [10]. Values of $\mathrm{I}_{\gamma \mathrm{r}} \leq 1$ corresponds to an annual effective dose of less than or equal to $1 \mathrm{mSv}$, while $\mathrm{I}_{\gamma \mathrm{r}} \leq 0.5$ corresponds to annual effective dose less or equal to $0.3 \mathrm{mSv}$ [11].

\section{Gamma Dose Rate}

The outdoor air-absorbed dose rates due to terrestrial gamma rays at $1 \mathrm{~m}$ above the ground level can be calculated from ${ }^{226} \mathrm{Ra},{ }^{232} \mathrm{Th}$ and ${ }^{40} \mathrm{~K}$ concentration values in soil assuming that the other radionuclides, such as ${ }^{137} \mathrm{Cs},{ }^{90} \mathrm{Sr}$ and the ${ }^{235} \mathrm{U}$ decay series can be ignored as their contributions are expected to be negligible to the total dose from environmental background $[12,13]$. The gamma dose rate (D) in the outdoor air at $1 \mathrm{~m}$ above the ground level can be calculated by equation (7).

$\mathrm{D}(\mathrm{nGy} / \mathrm{h})=0.462 \mathrm{C}_{\mathrm{Ra}}+0.621 \mathrm{C}_{\mathrm{Th}}+0.0417 \mathrm{C}_{\mathrm{K}}$

\section{Preparation Samples}

The studied samples were brought from Iraqi market includes rice and salt. The rice includes five types from different countries, amber and poor rice these two types are made in Iraq, also Mahmood, Gold types and 8 stars are made in India. Salt also includes five types from different countries, Al Mansuor, Poor rice, Al Nasoor, Dubai and Zer the first two types are made in Iraq and the others are made in Iran, United Arab Emirates and Turkey respectively as shown in Fig.(1). These elements rice and salt are very important in our life and our food almost eaten daily, so we collect ten types of the most famous models traded in the Iraqi market and calculated concentration of natural and artificial radioactive isotopes. The samples were examined in Sodium Iodide NaI(Tl) detector. All data were measured at the January of 2015.

\section{Results, Discussion and Conclusions}

The samples that have been assembled by 10 samples of rice and salts that obtainable in Baghdad markets and made in different countries the rice includes 5 samples Mahmood, Gold, the 8 star, Ammber and poor rice and salt also includes 5 samples AlMansour, Al-Nasoor, zer, Dubai and poor salt have been studied. All the results of the Naturally Radioactive Materials were measured by using sodium iodide enhanced with thallium $\mathrm{NaI}(\mathrm{Tl})$ ) spectroscopy. 
All the results of the naturally radioactive materials measurements, which were measured in this work, can be categorized into ${ }^{226} \mathrm{Ra}$, ${ }^{232} \mathrm{Th}$ and ${ }^{40} \mathrm{~K}$, and for artificial isotopes ${ }^{131} \mathrm{I}$, was investigated. Specific activity (SA) and its radiation hazard indices, which contented the gamma dose rate (D), the radium equivalent activity (Raeq), the external and internal hazard indices (Hex, Hin), the representative level index, (I $\gamma \mathrm{r})$, and the annual effective dose equivalent (AEDE), were estimated. In order to get accurate and confident results, measurements for each parameter such as S.A (for each isotope such as ${ }^{226} \mathrm{Ra}$ ) have been done for ten different samples, then the average of these measurements have been taken as a final result.
Naturally Radioactive Materials in rice and salt samples

The specific activities (SA) of ${ }^{226} \mathrm{Ra},{ }^{232} \mathrm{Th}$ and ${ }^{40} \mathrm{~K}$ and ${ }^{131} \mathrm{I}$ isotopes are shown in Table(1).

Table (1)

The specific activity for ${ }^{40} \mathrm{~K},{ }^{226} \mathrm{R},{ }^{232} \mathrm{Th}$ and ${ }^{131} \mathrm{I}$ isotopes in all samples.

\begin{tabular}{|c||c|c||c||c|}
\hline Samples & ${ }^{40} \mathbf{K}(\mathbf{B q} / \mathbf{k g})$ & ${ }^{226} \mathbf{R a}(\mathbf{B q} / \mathbf{k g})$ & ${ }^{232} \mathbf{T h}(\mathbf{B q} / \mathbf{k g})$ & ${ }^{131} \boldsymbol{I}(\mathbf{B q} / \mathbf{k g})$ \\
\hline \hline 8stars-rice & 460.037 & 5.548 & 5.582 & 2.603 \\
\hline Moh-rice & 550.181 & 11.322 & 6.015 & 5.312 \\
\hline Gold-rice & BDL* & 10.042 & 13.523 & 4.712 \\
\hline Poor-rice & BDL & 27.142 & BDL & 12.735 \\
\hline Amber & 731.454 & 15.349 & 19.753 & 7.202 \\
\hline Mns-salt & 415.609 & 6.517 & 4.157 & 3.058 \\
\hline Zer-salt & 292.517 & 5.561 & 11.737 & BDL \\
\hline Nsr-salt & 5204.084 & BDL & BDL & BDL \\
\hline \hline poor-salt & 439.879 & 7.657 & 20.242 & BDL \\
\hline Db-salt & 782.4018 & BDL & BDL & BDL \\
\hline \hline Average & 621.219 & 5.548 & 5.582 & 2.603426 \\
\hline
\end{tabular}

\section{* BDL: below detection limits}

Results show the maximum value of SA of ${ }^{226} \mathrm{Ra}$ was $27.142 \mathrm{~Bq} / \mathrm{kg}$. The high value of the SA found in the poor rice sample and the minimum value was in Al-Nasoor salt and Dubai salt samples.

Also the maximum value of the $\mathrm{SA}$ to the ${ }^{232} \mathrm{Th}$ isotope was $20.242 \mathrm{~Bq} / \mathrm{kg}$, the high value of the SA found in Poor salt sample, and the minimum value was in Al-Nasoor salt, Dubai salt and Poor rice. At last we observe the maximum value of the $\mathrm{SA}$ to the ${ }^{40} \mathrm{~K}$ isotope be $5204.084 \mathrm{~Bq} / \mathrm{kg}$. This isotope has energy $1416 \mathrm{kev}$ and return to ${ }^{40} \mathrm{~K}$ series, this highest value of specific activity came from dividing the energy of the isotope on sample weight, this sample called Al-Nasoor salt. While the Gold rice and poor rice has the lower value of SA. Where they were blow the detection level. All these values represented the specific activity (SA) to the natural radioactive isotope.

Our sample also includes industrial radioactive. The artificial isotopes are not found in the nature but we get them by industrialization, such as Iodine ${ }^{131} \mathrm{I}$ isotope. The SA to this artificial isotope $\left({ }^{131} \mathrm{I}\right)$ we note the maximum value of the SA of ${ }^{131}$ I was $12.73 \mathrm{~Bq} / \mathrm{kg}$, this value was formed in poorrice sample. But Al-Nasoor, Zer, poor salt and Dubai samples formed values below the detection level see Fig.(1). 


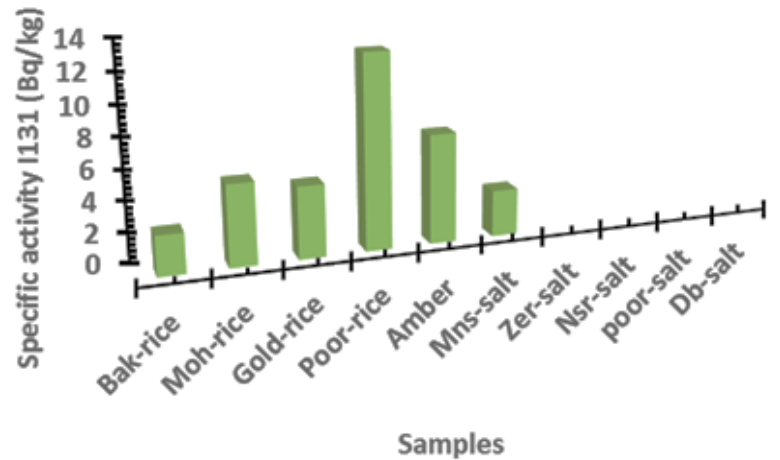

Fig.(1): Histogram of the concentration of ${ }^{131} \mathrm{I}$ in the rice and salt sample.

\section{Hazard Indices}

\section{Radium equivalent (Raeq)}

Table (2) illustrates all the calculated hazard indices. However, the average value of radium equivalent activities (Raeq) of gamma dose rate for the full rice and salt samples set were determined using eq. (1) to be 54.599 $\mathrm{Bq} / \mathrm{kg}$. While the maximum value of Raeq was $400.714 \mathrm{~Bq} / \mathrm{kg}$ in Al-Nasoor salt and the minimum value of Raeq was $27.142 \mathrm{~Bq} / \mathrm{kg}$ in poor-rice sample.

\section{Gamma Dose Rate}

Fig.(2) shows the average value of the gamma dose rate (D) for the full samples set of salt and rice samples were found to be $28.919 \mathrm{nGy} / \mathrm{h}$, which was calculated using eq. (7). The maximum value was $217.010 \mathrm{nGy} / \mathrm{h}$ for Nsr- salt and the minimum value was $12.539 \mathrm{nGy} / \mathrm{h}$ for poor rice.

\section{External and internal hazard index}

The average values of the external and internal hazard indices (Hex and Hin), which calculated using equations 4 and 5, were 0.147 and 0.155 . The maximum value of Hex was 1.082 in Al-Nasoor salt sample and the minimum value was 0.073 in poor rice sample. And the maximum value of Hin was 1.081 in Al-Nasoor salt sample and the minimum value was 0.1065 in Gold rice sample. It was found that all Hex and Hin had the normal range and all below unity.

Table (2)

Hazard indices in all samples are studied.

\begin{tabular}{|c||c||c||c||c||c||c|c|}
\hline Sample & $\begin{array}{c}\text { Raeq } \\
(\mathbf{B q} / \mathbf{k g})\end{array}$ & $\boldsymbol{D}(\mathbf{n G y / h )}$ & Hex & Hin & Iyr & $\begin{array}{c}\text { AEDE } \\
\text { outdoor }\end{array}$ & $\begin{array}{c}\text { AEDE } \\
\text { indoor }\end{array}$ \\
\hline \hline 8stars-rice & 48.954 & 25.213 & 0.132 & 0.147 & 0.399 & 0.030 & 0.123 \\
\hline \hline Moh-rice & 62.289 & 31.909 & 0.168 & 0.198 & 0.502 & 0.039 & 0.156 \\
\hline \hline Gold-rice & 29.381 & 13.037 & 0.079 & 0.106 & 0.202 & 0.015 & 0.063 \\
\hline Poor-rice & 27.142 & 12.539 & 0.073 & 0.146 & 0.180 & 0.015 & 0.061 \\
\hline Amber & 99.918 & 49.859 & 0.269 & 0.311 & 0.787 & 0.061 & 0.244 \\
\hline Mns-salt & 44.464 & 22.923 & 0.120 & 0.137 & 0.362 & 0.028 & 0.112 \\
\hline \hline Zer-salt & 44.869 & 22.056 & 0.121 & 0.136 & 0.349 & 0.027 & 0.108 \\
\hline \hline Nsr-salt & 400.714 & 217.010 & 1.081 & 1.081 & 3.469 & 0.266 & 1.064 \\
\hline \hline Poor-salt & 70.475 & 34.451 & 0.190 & 0.211 & 0.546 & 0.042 & 0.169 \\
\hline \hline Db-salt & 60.244 & 32.626 & 0.162 & 0.162 & 0.521 & 0.040 & 0.160 \\
\hline \hline Average & 54.599 & 28.919 & 0.147 & 0.154 & 0.460 & 0.035 & 0.141 \\
\hline
\end{tabular}

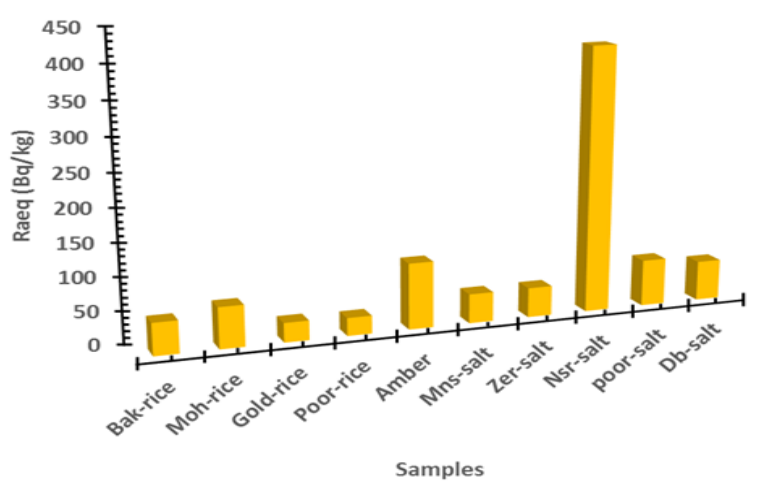

Fig.(2): Histogram of the radium equivalent activity in rice and salt samples.
The values of the Hex and Hin indices must be less than unity $(<1)$ for the radiation hazard to be negligible, but in Al-nasoor sample, the value of this indices was greater than the unity $(>1)$. For these high-values we suggest blocked or reduce this import and that will be strict control, this is the best works which must be implemented to get rid of this sample (Al-Nasoor salt). The measured level of natural radioactivity in the present study for the ten samples from rice and salt, give us 
beneficial fitting relationships between indices.

Fig.(3) and (4) show summary for the dose rate values (D $n G y / h$ ) with external and internal hazard indices (Hex and Hin), obtained in the current study.

\section{Representative level index (I $\gamma \mathbf{r})$}

The average value of the representative level index (I $\gamma \mathrm{r})$ for all samples set was 0.460554 determined using eq. (6), whereas the maximum value was 3.469 in Al-Nasoor salt, and the minimum value was 0.180 in poor rice. Fig.(5) illustrates the representative level indices, (I $\gamma \mathrm{r})$ and the dose rate in $\mathrm{nGy} / \mathrm{h}$.

\section{Annual Effective Dose}

To estimate the annual effective dose rates, the conversion coefficient from absorbed dose (D) in air to effective dose, $0.7 \mathrm{~Sv} / \mathrm{Gy}$ was used for the conversion coefficient from absorbed dose in air to effective dose received by adults.

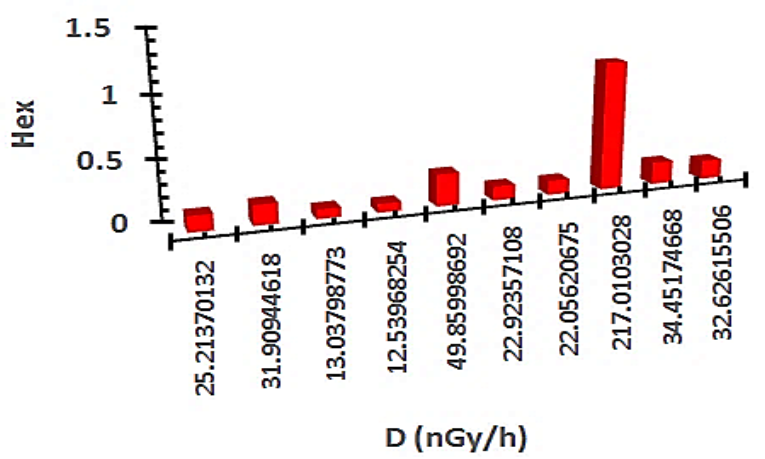

Fig.(3): Histogram of Hex as a function of $D(n G y / h)$ in all samples.

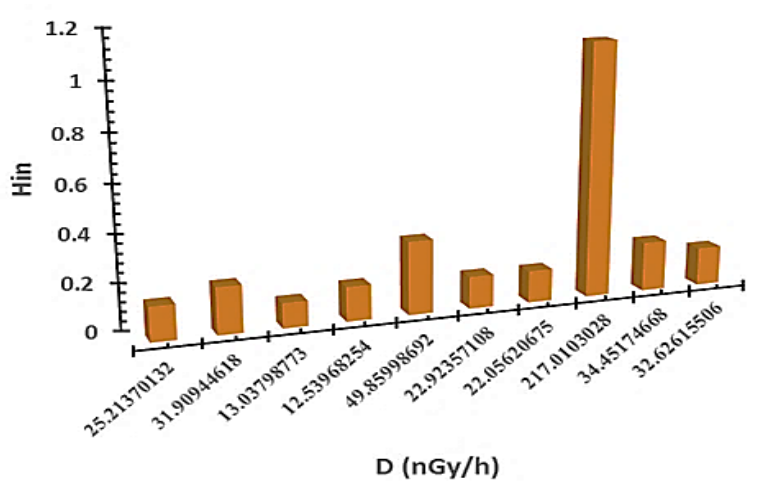

Fig.(4): Histogram of Hin as a function of $D(n G y / h)$ in rice and salt samples.

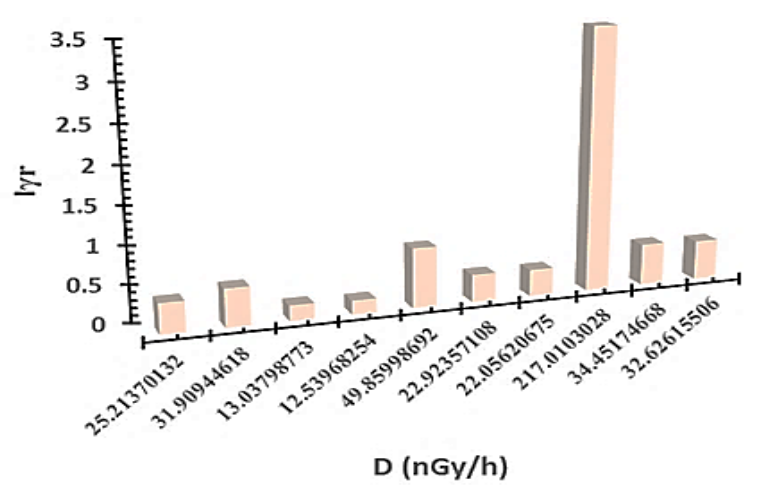

Fig.(5): Histogram of I $\gamma r$ as a function of $\mathrm{D}(\mathrm{nGy} / \mathrm{h})$ in the rice and salt samples.

For the indoor occupancy factor, 0.8 was used that implying $20 \%$ of time is spent outdoors, and for outdoor occupancy factor, 0.2 was used, which proposed by [14]. The indoor and outdoor effective dose rate $(\mathrm{E})$ in units of $m S v / y$ were calculated using equations 2 and 3, respectively. The average values of the annual effective dose equivalent (AEDE) due to terrestrial gamma radiation indoors and outdoors obtained for rice and salt samples set were 0.142 and $0.035 \mathrm{mSv} / \mathrm{y}$. The maximum value of AEDE (Indoor) (mSv/y) was 1.064 in the salt sample of Al-Nasoor, and the minimum value was 0.062 in the samples of Poor rice, and the maximum value of AEDE (Outdoor) (mSv/y) was 0.266 in the salt sample of Al-Nasoor, and the minimum value was 0.0153 in the poor rice sample.

\section{Conclusions}

This study showed that the average quality of the specific activities of uranium 238 was $5.55 \mathrm{~Bq} / \mathrm{kg}$, thorium 232 was $5.6 \mathrm{~Bq} / \mathrm{kg}$ and potassium 40 was $621 \mathrm{~Bq} / \mathrm{kg}$, while the content of iodine 131 was $2.6 \mathrm{~Bq} / \mathrm{kg}$. Measurements of hazard indices show that the concentrations of these isotopes in all samples are within the allowable limits internationally except NSR sample which was the total of Hinternal and Hexternal indices more than one. 


\section{References}

[1] Mohammad. A. K. and Arsalan M. G., "Environmental Pollution: Its Effects on Life and its Remedies" Journal of Arte, Science and Commerce, Vol. (2), No. (1), pp. 276-285, 2011.

[2] Sibel A., Ömer S., Erdal K., Sule K. and MAHMut d. "Radioactivity Levels in Some Mushroom Species and Consequent Doses" Asian Journal of Chemistry, Vol. (26), No. (3), pp. 879-882, 2014.

[3] George F. A. and Mark P. A. "Foodstuffs and Cancer: Analysis of Radionuclides and its Radiation Levels in Common Ghanaian Maize" International Journal of Sciences: Basic and Applied Research, Vol. (12), No. (1,) pp. 1-7, 2013.

[4] George F. A. and Mark P. A., "Environmental Pollution and Control Within Sabo Area of Ogbomoso in Oyo State of Nigeria" International Journal of Sciences, Basic and Applied Research (IJSBAR) Vol. 10, No. (2), pp. 329-338, 2012.

[5] Elase J. B. "Radon, Radium and Uranium in Drinking Water", Lewis Publisher, Washington DC, pp. 203-213, 1990.

[6] Elase J. B. and Peter J. M., "Natural Radioactivity of Australia Building Materials Industrial Wastes and byproducts" Journal of Health Physics, Vol. (48), No. (4), pp. 87-95, 1985.

[7] Ahmed K. S. and Nadeem A. "Assessment of radioactivity and associated hazards in local and imported cement types used in Sudan", Radiation protection Dosimetory, Vol. (88), No. (2), pp. 225-260, 2010.

[8] Ramero, G. V., Nymarr S., Ronaldee M. A., Kasimer M., Jamez B., Marselo I., Jonathan, G. A., Amerian M.A. S., Bassi M., Carlos C., Masimo B. F. and Noorian K. U. "Measurement of natural radioactivity in Brazilian beach sands" Radiation measurement, Vol. (41), No.(5), pp.189-196, 2006.

[9] NEAOECD; Nuclear energy agency, "Exposure of radiation from natural radioactivity in building material". Report by NEA group of experts. OECD, Paris 1979.
[10] Mohammed T., Nathera A., Saeed. J., and Talal H. "Natural radioactivity hazards of building bricks fabrication from soil of two districts of Pakistan", Journal of radiological protection Vol. (27), No. (1), pp.481-492, 2007.

[11] Sozan T. and Lwise G. "Determination of specific activity of ${ }^{226} \mathrm{Ra},{ }^{232} \mathrm{Th}$ and ${ }^{40} \mathrm{~K}$ for assessment of radiation hazards from Turkish plumice samples", Journal of environmental radiation, Vol. (2), No. (3), pp. 122-130, 2007.

[12] Khon C. L., Seong Y. L. and Cyan B. P. "Gamma radiation dose from radio nuclides in Hong Kong soil", Journal of Environmental and Radioactive Vol. (11), No. (1), pp. 279-290, 1990.

[13] UNSCEAR, United Nations Scientific Committee on the Effects of Atomic Radiation, "Sources and Effects of Ionizing Radiation. United Nations", New York (1993).

[14] UNSCEAR; "Exposures from Natural Sources", Report to General Assembly, Annex, New York (2000).

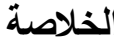

في هذه الدراسة تم قياس تركيز النشاط الأشعاعي النوعي

النظائر المشعة الطبيعية المنشأ في عينات مختارة من الرز وملح الطعام المتوافر في الاسواق المحلية في بغداد ومن ثم حساب معاملات الخطورة الناجمة عنها وكذلك نت حساب تركيز اليود المشع في هذه العينات بأستخدام منظومة كاشف يوديد الصوديوم المطعم بالثاليوم. اظهرت هذه الدراسة ان

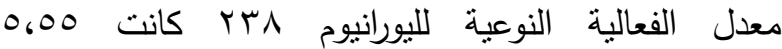
بكريل/كغ والثوريوم rس كانت • ك كانت ابT بكريل/كغم بينما كان محتوى اليود rا بآ، بكريل/كغ.

من حساب معاملات الخطورة تبين ان تراكيز هذه النظائر في جميع العينات هي ضمن الحدود المسموحة دوليا عدا عبنة Al-Nasoor التي كان مجموع معاملي الخطورة الداخلي والخارجي فيها اكثر من واحد. جميع البيانات نم قياسها في كانون الثاني 10 • ب. 